\title{
СОЦІАЛЬНІ ТА ПЕДАГОГІЧНІ УМОВИ ФОРМУВАННЯ МОРАЛЬНИХ ТА ОСОБИСТІСНИХ ЯКОСТЕЙ СТУДЕНТІВ В ОДЕСЬКОМУ ОБЛАСНОМУ БАЗОВОМУ МЕДИЧНОМУ УЧИЛИЩІ
}

\author{
О. С. Кузьміна
}

Одеське обласне базове медичне училище

У даній статті розглянуто досвід роботи з питань соціальних та педагогічних умов формування моральних та особистісних якостей студентів в Одеському обласному базовому медичному училищі.

\section{SOCIAL AND EDUCATIONAL CONDITIONS OF FORMING MORAL AND INDIVIDUAL QUALITIES OF STUDENTS IN ODESA REGIONAL BASIC MEDICAL SCHOOL}

\section{O. S. Kuzmina}

\section{Odesa Regional Basic Medical School}

The article deals with experience of work about social and educational conditions of forming moral and personal students' qualities in Odesa Regional Basic Medical School.

Вступ. Актуальність проблем виховання молоді пов'язана з глибокими соціальними змінами в суспільстві. Україна переживає дуже складний етап свого розвитку. Починаючи з листопада 2013 року, суспільство і молодь перебувають в духовних пошуках. Насамперед молодь постала перед викликами часу, вона проходить переосмислення своїх позицій, прагне відродження нашої держави, української нації. Патріотизм - це вже не просто напрям виховання - це стиль життя студентської молоді. Події грудня 2013 року, січня, лютого 2014 року розділили життя українського народу. Війна залишила слід у серці кожної людини. Студентська молодь перебуває в центрі уваги різних політичних напрямів. Значно знизився рівень життя, зростає агресивність, насилля в суспільстві, сім'ї, є духовна і моральна криза, гинуть молоді люди від наркотиків, від соціальних хвороб, ВІЛ-інфекції, туберкульозу. Саме тому, що $є$ визнання існування таких глибоких проблем, визначена головна мета - це виховання кожного студента і забезпечення умов для розвитку і саморозвитку сучасної студентської молоді.

Основна частина. Складовими процесу виховання студентів $\epsilon$ підтримка, заохочення, посилення надії, стимулювання кожного студента до розвитку і саморозвитку.

(C) О. С. Кузьміна, 2016
В сучасних умовах ланцюжок «викладач - вихователь - наставник» набуває об'ємнішого значення. Модель виховання, коли викладач - центральна фігура в освітньому процесі, дещо змінилась. Переорієнтація ролі викладача, насамперед у творче змагання, колективну працю, пошук правильної відповіді на запитання, спрямована на спонукання до самостійного отримання знань студентами.

Поняття терміна «моральність» трапляється ще в працях стародавніх філософів. Моральність - це здатність особи до виконання обов'язку. «Стати досконалим громадянином» - це здатність жити в гармонії людини і громадянина. Такі поняття дали Арістотель і Платон. В античні часи була сформульована ідея морального виховання з їі культом вільної, гордої, з почуттям власної гідності особистості. В середні віки особистість була принижена. Але в епоху відродження ідея моральності набуває нового змісту і розуміння. Теорія виховання «для інших і для самого себе»- це теж прояви моральної позиції багатьох поколінь [1].

В історії і літературі є цікаві приклади, які примушують ставити запитання і відповідати на них. Один з прикладів: оповідання А. П. Чехова «Попрыгунья», де головний герой Йосип Степанович Димов. На заняттях із теми «Дифтерія» студентам ставимо питання чому і навіщо лікар Димов з ризиком для свого життя 
рятував хвору дитину і чи було це обов'язковим, чи можна було уникнути цього?

Інший приклад - історія лікаря Гааза. Він був дуже відомий, мав велику практику і прибутки від своїх пацієнтів, жив у багатстві та спокої, але одна подія зовсім змінила його життя. Лікаря викликали до в'язниці, і те, що він побачив, перевернуло його життя. Він роздав своє майно, відмовився від дорогого будинку, і пішов працювати до в'язниці. Гааз подолав шлях каторжника, закував себе у кайдани, щоб довести, що нелюдське ставлення до людей не може бути виправдано ніякими провинами людей. Що морально, що аморально, де правильний шлях, а де помилка, студент ставить ці питання і самостійно шукає відповіді [2].

Термін «мораль» не можна розглядати без поняття «патріот» і «громадянин». Це взаємопов'язано.

Життя готує багато випробувань, і тому в молоді повинні бути добре розвинуті моральні якості, які допоможуть зробити правильний вибір. Лише моральні цінності стимулюють зусилля людини, допомагають вирішувати наявні у житті і діяльності суперечності. Тим самим моральні цінності в кінцевому результаті дозволяють людині більш повно виразити себе, розвити свої здібності, свою творчість, неповторність, індивідуальність.

Плануючи виховну роботу в медичному училищі розроблені і обґрунтовані соціально-педагогічні умови становлення моральних якостей студентів. Багаторічний досвід проведення цієї роботи доводить, що соціально-педагогічні умови сприяють становленню самооцінки моральних якостей студентів, враховують особливості самосвідомості, формування самооцінки моральних якостей, забезпечують формування базових умінь для здійснення самоаналізу моральної поведінки.

В училищі проводиться робота з педагогічної діагностики рівня розвитку морально-ціннісних орієнтацій та самооцінок моральних якостей студентів, наголошені на адекватності самооцінки. Як показують дослідження, в багатьох випадках самооцінка буває заниженою або не є об'єктивною.

Матеріали навчально-методичних тренінгів, анкетувань забезпечують позитивну динаміку самооцінок особистісних моральних якостей студентів у позанавчальній діяльності протягом навчання.

Досвідчені педагоги спостерігають, спілкуються, анкетують з метою визначення рівня готовності студентів до самооцінки особистісних якостей, з'ясовують самооцінку власних моральних якостей і параметри системи морально-ціннісних орієнтацій.
Тренінги «Пізнай себе», «я хочу», «я можу» допомогли визначити напрями роботи. Дослідники доводять: самооцінка, ціннісні орієнтації безпосередньо пов'язані з процесом самоактуалізації особистості студента, його морального самовдосконалення, в яких вміщена потенційна духовна енергія.

Рівень і логіка сучасного розвитку педагогічної науки поставили питання про посилення ролі і значення врахування в навчально-виховному процесі особливостей таких утворень, якими $є$ самооцінка та ціннісні орієнтації, що безпосередньо пов'язані з процесом самоактуалізації особистості студента, його морального самовдосконалення.

Процес морального становлення особистості без урахування зв'язків з історичними, економічними, політичними, психологічними явищами в суспільстві неможливий [3].

Всі сучасні виховні концепції доводять, що студент у більшості випадків сприймає себе позитивно, вміє жити з іншими людьми, відкритий для досвіду, проявляє милосердя, довіряє іншим, хоче отримувати знання, має потребу в оцінках своїх здібностей, поважає дружбу і гідність, особливо оцінює взаємодопомогу.

В умовах великого навантаження під час навчального процесу - лекції, практичні заняття, семінари - багато студентів повинні самостійно вирішувати складні життєві питання, дехто із студентів працює, щоб допомагати батькам, інші виїжджають з рідних міст, залишаються без допомоги своєї сім'ї, що потребує організованості, здатності самостійно мислити і приймати рішення, бути відповідальним за свої дії. Таким чином, кожна молода людина створює себе і свою модель поведінки, але без допомоги і підтримки педагогів цей процес буде більш складним і тривалим. Досвід, який набувається самостійно, приносить велику користь, а новий досвід породжує необхідність переосмислення засвоєного, звичайно цей процес $\epsilon$ тривалим, він потребує аналізу, висновків. Коли студент виходить за межі звичайних умов і обставин, починає проявляти ініціативу, творчість, тоді проявляється самостійність, засоби реалізації його діяльності у конкретному випадку. Свідомо вдосконалюючи свої моральні якості, людина водночас сприяє удосконаленню моралі суспільства. Ми проводимо анкетування студентів, яке показує, що більше половини студентів І курсу здатні на добрі вчинки заради інших студентів, але дуже пасивні у випадках, де необхідно вступити у конфлікт, щоб відстоювати інтереси інших студентів. Формується усвідомлення про моральні вчинки, але немає самооцінки моральних якостей, що пов'язано 
з відсутністю досвіду, активного прояву моральних якостей. В студентів II-III курсів досвід самооцінки більш розвинутий, переважно студенти чітко розуміють, як потрібно вчинити. Кожний студент може і повинен уміти регулювати свою поведінку, долати труднощі, вирішувати складні питання.

У багатьох студентів старших курсів (за результатами досліджень керівників навчальних груп III-IV курсів) проявляється гнучкість у самооцінці, вміння коригувати свою поведінку під впливом досвіду, що допомагає адаптуватися людині до умов життя. Викладачами училища підтримується «ситуація успіху». Наприклад, викладач ставить запитання, на яке свідомо знає, що буде отримана правильна відповідь, для студента важливо схвалення, підкреслення маленького успіху, підтримка і повага. Труднощі студентів, нові вимоги, навантаження, хронічна втома, невпевненість у власних силах, страхи, тривожність знижують працездатність і ускладнюють навчальний процес.

Керівники навчальних груп першого року навчання сприяють безболісному періоду адаптації. 3 досвіду роботи виділено такі етапи: реалізація пропедевтичного підходу, спостереження і аналіз, корекційна робота в разі серйозних адаптаційних порушень. Аналіз діяльності керівників навчальних груп показав, що такий компетентний підхід запобігає дезадаптації і сприяє успішному навчанню і розвитку особистості.

Формування студента з соціально-моральною позицією - активний педагогічний процес. В нашому училищі проводяться лекції, бесіди, диспути, тематичні вечори, тижні, конкурси, вечори запитань і відповідей. Якщо не буде досягнута виховна мета - це призведе до внутрішньої кризи, а цього не можна допустити. Тому на І курсі - криза очікування «важко», «багато треба вчити», на III курсі - криза самовизначення «я можу ще мало», на IV курсі - криза професійної адаптації (це хвороби духовного зростання, їх треба пройти з найменшими втратами).

В Одеському обласному базовому медичному училищі (ООБМУ) працює багато досвідчених викладачів. Проводяться цікаві загальноучилищні заходи: до Всесвітнього дня боротьби зі СНІДом, до Дня Україн-

\section{ЛІТЕРАТУРА}

1. Нарійчук М. Д. Соціально-педагогічні умови становлення самооцінки особистісних моральних якостей студентів медучилища у позанавчальній діяльності : дис. ... канд. пед. наук : 13.00.05 / М. Д. Нарійчук; Нац. пед. ун-т ім. М. П. Драгоманова. - К., 2006. - 201 с.

2. Сухомлинська О. Сучасні цінності у вихованні: проблеми, перспективи / О. Сухомлинська // Шлях освіти. 1996. - № 1. - С. 24-27. ського війська, до Свята української писемності і мови, прийом до лав українських козаків, до Дня студентів, до Дня викладачів, акції зі збору коштів на підтримку захисників України, акції «Милосердя», «Від серця до серця», правове виховання, гендерна культура. В училищі проводяться конкурси «Краща медсестра», «Краща акушерка», «Кращий фельдшер», «Міс училища». Під час волонтерської роботи студенти працюють у дитячих будинках, опікуються дітьми-сиротами. Багато листів подяки надійшло адміністрації нашого училища від керівників лікувальних установ м. Одеси.

Наше головне надбання - це формування відповідального, професійного і гуманного ставлення до роботи наших студентів.

Виховання студентів в ООБМУ - це процес безперервний. Основне завдання педагогічного колективу це виховання гідних, високопрофесійних фахівців для роботи в лікувальнихустановах нашої держави. Ввійшло в практику: протягом трьох років після випускуучилищем досліджується не лише професійна адаптація випускників, а і рівень відповідності стійких моральних орієнтирів, загальнолюдських цінностей, орієнтація на самовизначення, самореалізацію набутих у процесі навчання.

Висновки. Передумовою розвитку самооцінки моральних якостей і моральної спрямованості студентів $\epsilon$ наявність знань про сучасне суспільство, людину. Залучення студентів до соціально-виховної діяльності $\epsilon$ важливою умовою успішного формування моральних якостей, накопичення позитивного досвіду взаємодії, спілкування з людьми різного віку, однолітками, при роботі в інтернатах створюють умови, при яких студенти дотримуються моральних норм.

Формування самооцінки моральних якостей в процесі виховної роботи - це тривалий і багатогранний процес, який є частиною самовизначення і самореалізації студента. Самооцінка формується під впливом оцінки педагога, батьків, ровесників. У педагога $\epsilon$ методичні прийоми - зауваження, схвалення, засудження, підтримка, погодження. Ці прийоми є вихідними даними для самооцінки студента. Педагог повинен акцентувати увагу на позитивних якостях студента, щоб корегувати його власні самооцінки.

3. Маковецький А. М. Формування морального світу особи та їі ціннісних орієнтацій в кризовий період життя суспільства : дис. ... доктора соціол. наук : 22.00.04 / А. М. Маковецький ; Чернівецький держ. ун-т ім. Ю.Федьковича. - Чернівці, 1994. - 300 с.

Отримано 02.02.16 